\section{Found Nest of The Great Grey Owl}

Ed Robinson, Wawanesa, Manitoba

The article appearing in the last issue about the Great Grey Owl interested me very much. According to Mr. A. G. Lawrence, of "Chickadee Notes", I have the only nesting report for Manitoba, except one at Carman in 1884. The one I found was at East Bay on the east side of Lake Dauphin, on May 14, 1926.

The nest was built in a Red-tailed Hawk's nest about 15 or 20 feet up in a poplar tree, growing on the south side of a large clearing. I can well remember seeing these hugh birds a quarter of a mile away. Three young, of different sizes, were in the nest. I also had one which I mounted myself. I cannot remember where it came from, but as usual it was shot by someone and given to me in the winter time.

\section{It Is A Foolish Bird}

K. E. Baines,

Tisdale, Sask.

I doubt if the Great Grey Owl is as rare as we are led to believe. In the big game hunting season of 1925 I shot one of these birds, mistaking it in the tree for a Horned Owl. The following summer I homesteaded and worked on a road construction job in the Prairie River district and saw these birds many times while roaming the adjacent bush. At that time the district south of Prairie River had not been settled, and the Great Grey Owl was fairly common. I always saw them in stands of large poplar during June and July.

I have seen them only once or twice in winter - more recently, during winter hunting at Leaf Lake, north-east of Hudson Bay, Sask., and then close to heavy spruce. The Great Gray Owl is a bird of the deep forest, occasionally sitting for long periods on the sunshiny side of a lake or other opening. It is very heavily feathered which probably indicates it is so equipped to withstand much cold. It is a very foolish bird as far as man is concerned and will remain in the same perch even after being shot at repeatedly with a heavy sporting rifle. Consequently it is quickly exterminated as settlement takes place.

\section{Great Horned Owl's Nest William Anaka, Spirit Lake}

On April 18 I located a Great Horned Owl's nest in the woods along the north-east side of Spirit Lake. While making my way to the nest through the brush, the female owl flew off and alighted on a tree about twenty yards away. Almost immediately she began uttering a high pitched whistle somewhat like a young bird in distress. At the same time she spread her wings and tail wide, and awkwardly walked a few steps along the branch. She flopped to a lower one and repeated the performance - then tumbled to the ground; all this time giving the distress whistle. This was, no doubt, a broken wing act to lure me away from the nest. Although I usually locate several Horned Owl nests every spring, this is the first time I have noted a performance like the one described.

When I climbed up to the nest there were three young owls, about a week old, inside. Also in the nest were five or six meadow mice. a pocket gopher and a rabbit leg. Underneath the nest were a number of crow feathers.

Although the Horned Owl is generally considered a bad actor, this family appeared to be on the best behaviour.

An unusual large flight of Buteo Hawks passed over the district from April 9 to 13. Most of these were in singles and pairs - several large flocks were noted. During a two hour stretch on the afternoon of April 11, I counted 52 hawks. In the mornings they could be seen everywhere perched in the trees where they rested for the night. An approximate estimate for the five days would be from 600 to 800 hawks.

Almost all of those identified were Red-tailed Hawks. Blacked phased birds were common. One of these I identified as a Harlan's Hawk. There were also several light colored individuals with just a trace of markings on the wings and belly, and cream-colored tails. 